\title{
PENERAPAN USHUL $A N$-NAHW DALAM PENYUSUNAN MATERI PEMBELAJARAN NAHW PEDAGOGIS
}

\author{
Khabibi Muhammad Luthfi
}

\author{
habibi.abeb@gmail.com \\ Institut Pesantren Mathaliul Falah Pati \\ Jl. Pati-Tayu KM.4 Purworejo Margoyoso Pati Jawa Tengah
}

\begin{abstract}
The study of Arabic syntax and the foundation is essentially in the Arab world there is a group that reconstruct the foundation in order to prepare syntactic and group developing pedagogical syntax essentially Arab and foundation combined with Western linguistics, but do not link it with language learning. This article would describe the concept of syntax as a basic foundation of Arabic linguistics epistemology that could be the basis of linguistic pedagogical education in Arabic. Furthermore, this article would identify its application in the preparation of teaching materials for students of pedagogical syntax Indonesia. While the study of Arabic syntax and essentially foundation in Indonesia, many educational institutions Arabic ignore their correlation. Based on linguistic approach to educational and library data analyzed by the text of discourse found that the basic foundation of Arabic syntax is the sama', qiyas, ijma', ta'lil, ta'wil, istihsan 'amil and istishhab. The application of the basic foundation of syntax as the basis for the preparation of learning materials is a pedagogical syntactic analysis of the basic foundations of syntax in generating syntax, allowance rules of syntax, classification of syntactic descriptive elements, comparing element with Indonesian and Arabic syntax and arrrange the teaching materials.
\end{abstract}

Keywords: Syntactic Foundation, Arabic Pedagogical, Learning Materials

\section{PENDAHULUAN}

Pembelajaran bahasa Arab di Indonesia seperti pesantren, madrasah dan Perguruan Tinggi Keagamaan Islam (PTKI) kadang 'mengabaikan' ushul an-nahw. Padahal seperti dijelaskan dalam kajian linguistik edukasional ('ilm al-lugah at-ta'limi) ilmu ini sangat signifikan untuk mengembangkan nahw ta'limi (pedagogis) (Hassan, 2000, h. 40 dan Parera, 1994, h. 13-17). Selain itu, banyak alumni lembaga pendidikan tersebut cenderung gagap ketika dihadapkan dengan teks bahasa yang berbeda dengan kurikulumnya. Alumi belum mempunyai kerangka berfikir untuk menganalisa realitas bahasa modern yang menggunakan tata bahasa deskriptif (washfi). Realitas bahasa Arab yang selalu berubah dibaca dalam kacamata nahw tradisional yang bersifat filosofis (falsafi).

Sementara para alumnus lembaga yang lebih menekankan pada aspek keterampilan, kurang mampu mengembangkan kompetensi tata bahasa Arab. Karena dalam proses pembelajaran yang dilalui mereka bersifat imitasi dan tiruan performansi para native Arab dan pendidik bahasa Arab (Chomsky, 1957, h. 26-28). Kalaupun dalam kurikulumnya mempelajari struktur Arab, itu sebatas pengenalan. Bahkan ada kecenderungan hanya memahami gramatika linguistik umum ('ilm al-lugah al-'amm). Padahal linguistik umum merupakan generalisasi-dalam aliran transformasi generatif disebut core grammar-kaidah-kaidah bahasa dunia, sehingga belum mampu menggambarkan karakteristik tata bahasa Arab (peripheral grammar) (Musni, 2009, h. 89). Selain itu, ketika menjadi pendidik para 
alumnus kurang mahir dalam mengembangkan materi-materi tata bahasa Arab modern ilmiah (al-lugah al-'arabiyyah almu'ashiah al-'ilmiyyah).

Hanya saja, untuk proses pembelajaran ushul an-nahw sebagai basis penyusunan materi pembelajaran nahw diperlukan proses yang tidak singkat. Ushul an-nahw sendiri merupakan ilmu yang-bisa jadi-sulit dikuasai pendidik dan konseptor bahasa Arab Indonesia. Jika ingin mendalami, para pendidik kemungkinan kesulitan menemukan referensi yang secara luas mengupasnya, karena secara umum pendalaman ushul annahw tidak 'semeriah' seperti 'ushul al-fiqh dalam hukum Islam, meskipun kedua-duanya sejajar dalam konteks sebagai basis epistemologi (Wahab, 2009, h. 190). Berdasarkan permasalahan tersebut tulisan ini menganalisa konsep ushul an-nahw dan penerapannya dalam pengembangan materi pembelajaran bahasa Arab, terutama nahw Pedagogis.

\section{Kerangka Konseptual}

Linguistik edukasional merupakan salah satu cabang linguistik terapan yang khusus menganalisis, menerangkan dan menjelaskan praktik pembelajaran dan pendidikan bahasa yang berlandaskan teori-teori kebahasaan ('ulum al-lugah) yang dihasilkan dari mikro linguistik seperti'ilm al-dalalah (semantik), 'ilm an-nahw (sintaksis), 'ilm ash-sharf (morfologi) dan 'ilm al-ashwat (fonologi) dan makro linguistik seperti psikolinguistik, sosiolinguistik, dan antropolinguistik (Stern, 1983, h. 44). Dengan kata lain, linguistik edukasional menjelaskan sekaligus mengembangkan teori dan praktik pembelajaran bahasa dengan kacamata linguistik-baca: ilmu-ilmu bahasa. Sementara unsur-unsur pendidikan atau pembelajaran seperti tujuan, pendidik, peserta didik, materi, metode, media, evaluasi dan lingkungan mengikuti "nalar" yang terdapat dalam bahasa sebagaimana yang disusun linguis. Dengan kata lain, argumentasi yang dibangun linguistik edukasional adalah proses penyusunan teori dan praktik pembelajaran bahasa harus dilahirkan atau didasarkan pada teori-teori bahasa.

Menurut D.J. Parera, pengaplikasian teori bahasa Arab agar memberikan kontribusi dalam pembelajaran bahasa Arab melalui tiga tahapan, yaitu linguistik, pemilihan dan pengajaran (Parera, 1994, h. 13-15). Dengan mengacu pada tahapan D.J Parera ini langkah awal dalam penyusunan materi pembelajaran bahasa adalah mengkaji bahasa atau ilmu bahasa yang dihasilkan para linguis terlebih dahulu. Setelah itu melakukan pengolahan terhadap ilmu-ilmu bahasa itu untuk dikembangkan menjadi teori atau praktik materi pembelajaran bahasa. Pada saat pengolahan inilah ilmu pendidikan beroperasi. Ilmu pendidikan akan dijadikan sebagai salah satu dasar untuk menyusun atau menyeleksi teori yang dihasilkan para linguis. Sehingga olahan ini akan menghasilkan teori atau praktik khusus materi pembelajaran bahasa. Pengolahan ini dilakukan oleh pendidik bahasa.

Dengan melihat alur di atas maka syarat utama pendidik bahasa adalah menguasai teori-teori bahasa. Ada juga sebagian pakar pendidikan bahasa yang mensyaratkan pendidik bahasa adalah linguis. Alasannya adalah agar proses pembelajaran bahasa itu bersifat up todate dan mandiri, sehingga dalam mengembangkan pembelajarannya, pendidik tidak mengunggu hasil dari linguis. Meski demikian untuk yang terakhir ini merupakan tipe idealis yang bisa jadi sulit diaplikasikan.

Salah satu contoh pengolahan dari ilmu bahasa murni menjadi ilmu bahasa pedagogis adalah penyusunan materi pokok pembelajaran tatabahasa Arab pedagogis yang dimulai dari kajian terhadap tata bahasa itu sendiri. Prosedur awal penyusunan ini adalah pemetaan tata bahasa Arab yang dihasilkan para nuhah atau linguis Arab. Setelah itu pendidik bahasa mengolahnya dengan teoriteori penyusunan materi pokok yang berupa prinsip, karakteristik dan prosedur penyusunan materi ajar dengan berprinsip pada kriteria tatabahasa pedagogis yaitu tata bahasa yang memiliki ciri seperti Menunjukkan penggunaan unsu-unsur tata bahasa dalam rangka memperoleh kemampuan berbahasa baik lisan maupun tulisan; Menjadi sumber untuk menjadikan bahan pengajaran bahasa pada tingkatan dasar; Berusaha memberikan sumbangan dalam pembelajaran bahasa terutama yang terkait dengan pola-pola kebahasaan; Digunakan istilah dengan kriteria yang ada, dikenal umum, lazim digunakan oleh masyarakat tutur bahasa itu sendiri dan dapat dipertanggungjawabkan secara ilmiah; Rumusan dibuat sederhana dan semudah mungkin yang sifatnya bukan memeriakan melainkan menggunakan penggunaannya; Kaidah-kaidah bahasa dirumuskan berdasarkan bahasa yang digunakan oleh masyarakat bahasa itu dan Setiap kaidah 
diberi tingkat penjenjangan engan urutan yang sistematis (Chaer, 1998, h. 1-12). Dari olahan ini menghasilan tata bahasa pedagogis yang mempunyai ciri dan karakteristik tertentu yang berbeda dengan tata bahasa arab murni.

\section{Metode Penelitian}

Secara keilmuan (teoritis) pendekatan atau sudut pandang yang dipakai dalam penelitian ini adalah pendidikan bahasa. Sedangkan secara metodologi, penelitian ini menggunakan pendekatan sintetik-heuristik (Tarigan, 2009, h. 55-59). Jenis penelitian ini adalah libary research. Sumber data penelitian ini dibagi menjadi dua, 1) data primer penelitian ini berupa kitab yang diklasifikasikan menjadi klasik seperti ushul an-nahw adalah al-Ushul fi an-Nahw karya Abu Bakr ibn Siraj (w. 316 H), al-Inshaf fi Masail alKhilaf bain an-Nahwiyyain al-Bashriyyin wa alKufiyyin karya Abu Sa'id al-Anbari (w. 328 H.), al-Khashaish karya Abu Fath al-Jinni (w. 392 H.) dan modern seperti Ihya' an-nahw karya Ibrahim Mushthafa (1888-1962 M.) dan alUshul Dirasah Ibistimulujiyyah li al-Fikr alLugawi 'ind al-'Arab; an-Nahw, Fiqh al-Lugah wa al-Balagah karya Tamam Hassan (1918sekarang), 2) data sekunder baik ushul anNahw dan 'ilm an-nahw dalam penelitian ini adalah Min Asrr al-Lugah karya Ibrahim Anis, Min Tarikh an-Nahw karya Al-Said al-Afgani (1986) dan Nasy'ah an-Nahw wa Tarikh Asyhur an-Nuhah karya Muhammad Thanthawi (1801-1873 M.)

Pengumpulan data penelitian ini menggunkan metode dokumentasi dan metode online (Bungin, 2008, h. 70-72). Selain itu peneliti sendiri menjadi instrumen penelitian yang secara sadar dan aktif memanfaatkan intuisi kebahasaan peneliti (Djajasudarma, 2006, h. 69 dan Mahsun, 2005, h. 75). Analisis data penelitian ini menggunakan analisis wacana internal teks (tahlil al-khithabi fi al-nash) dengan dua metode, yakni analisis linguistik (at-tahlil allugawi) dan intertektualitas teks (tahlil altanashsh) (al-Kulli, 1995, h. 57).

\section{HASIL DAN PEMBAHASAN Ushul an-Nahw sebagai Dasar Penyusunan Nahw}

Ushul an-nahw berasal dari bahasa Arab yang terdiri dari kata ushul dan Nahw. Secara etimologi kata ushul merupakan bentuk jamak (plural) dari kata ashl yang berarti dasar yang menjadi pondasi atau sesuatu yang melandasi yang lain (pondasi). Kata ushul juga dimaknai sebagai sesuatu yang dibutuhkan dan tidak butuh pada yang lain (Mushthafa, 1972, h. 908). Secara terminologi kata nahw sudah menjadi konsep khusus yang digunakan dalam tatabahasa Arab. Jika merujuk pada linguistik modern, nahw sejajar dengan konsep sintaksis. Perbedaan keduanya hanya terletak pada objek material keilmuannya. Objek material nahw adalah bahasa Arab, sedangkan sintaksis bahasa secara umum. Seperti diungkapkan Martin J. McDermott (1993) nahwu adalah ilmu yang khusus membahas keadaan setiap akhir kata baik yang mu'rab (berubah) atau yang mabni (tetap) dalam sebuah kalimat (McDermott, 1993, h. 635).

Penggabungan dua konsep tersebut mempunyai konsekuensi pada pengertiannya. Secara khusus Muhammad 'Id (2006, h. 5) mendefiniskan ushul an-nahw sebagai prinsipprinsip yang melandasi ilmu nahw dalam berbagai persoalan dan aplikasinya. Ushul annahw juga didefiniskan sebagai ilmu yang membahas tentang adillah an-nahw secara universal baik dari segi kaidah-kaidah, dalildalil, motode istinbat (cara penggalian dan penyusunan teori) dengan dalil-dalil tersebut, maupun aplikasinya. Sebagai ilmu yang melahirkan teori-teori nahw tentunya ushul an-nahw memiliki prosedur ilmiah. Prosedur ilmiah ini setidaknya melalui empat tahap, yaitu penentuan sumber data, cara pengambilan, cara merekonstruksi data dan verifikasi data. Atau dengan meminjam teori Hughet (1968, h. 12), prosedur pengilmiahan bahasa Arab ada lima, yaitu mengumpulkan data, mengklasifikasi data, membentuk hipotesis baru, memeriksa dan menguji hipotesa itu dengan data baru dan menetapkan prinsip ilmiah baru yang konsekuen. Berdasarkan pendapat ulamaulama ini metode ushul an-nahw yang digunakan dalam historisitas nahw adalah sama', qiyas, ijma', ta'lil, 'illah, ta'wil, istihsan dan istishhab. Berikut akan dijelaskan masingmasing konsep itu.

Pertama, sama'. Sama' atau sima' secara etimologi adalah mendengar atau mendengarkan. Sementara dalam termilogi ushul an-nahw berarti penelitian dengan cara mendengarkan atau melihat peristiwa tutur yang dilakukan oleh masyarakat Arab. Jadi sama' tidak hanya menggunakan pendengaran saja, melainkan mengunakan pengamatan. Kedua, qiyas. Secara etimologi qiyas adalah attaqdir yang berarti memprediksi atu mengirangira. Dalam kamus Munjid qiyas terambil dari kata qasa yaqisu qaisan qiyasan artinya qaddar atau menyamakan (Maluf, 2010, h. 665). 
Sementara kitab al-Batsit fi Ushul an-Nahw wa Madarisih menjelaskan bahwa secara harfiah kata qiyas diartikan sebagai membandingkan kata dengan kata, bentuk dengan bentuk dengan menjaga konteks keasliannya. Sementara Tamim Allah (2004, h. 39) menjelaskan bahwa qiyas setidaknya bisa dimaknai menjadi tiga yaitu menyamakan sesuatu yang belum diketahui dengan yang sudah diketahui, sesuatu yang belum jelas terhadap sesuatu yang sudah jelas atau sesuatu yang belum didengar terhadap sesuatu yang sudah didengar mengenai satu dari beberapa hukum yang berlaku dengan menyertakan alasan yang tepat mengenai keduanya.

Ketiga, ijma: Secara etimologi ijma memiliki makna 'azm 'ala al-amr yang berarti menyegaja atau mepunyai niatan dalam suatu kasus dan ittifaq yang bermakna kesepakatan. Pengertian pertama menunjukkan ijma' bisa dilakukan satu orang, sementara yang kedua mengharuskan batas minimalnya adalah dua. Dalam konteks ushul an-nahw ijma' diartikan sebagai metode yang mneunjukkan adanya kesepakatan antara ulama Basrah dan Kufah mengenai suatu teori bahasa Arab. Definisi ini mengungkapkan bahwa metode ijma' lahir setelah kedua mazhab itu. Bila ditelusuri metode ini muncul dicetuskan mazhab Bagdad. Mazhab ini dianggap sebagai mazhab yang melakukan kajian tashhih dan tarjih terhadap kedua mazhab tersebut (ibid, h. 52).

Keempat, ta'lil. Pembahasan yang yang paling penting lain dalam ushul an-nahw adalah proses mencari 'illah atau ta'lil yakni mencari sebab suatu hukum. Ini adalah pengertiannya secara etimologi. Atau, 'illah adalah sebuah makna yang menempati suatu posisi di mana posisi yang ditempati itu berubah karenanya dengan tanpa sengaja. Ta'lil dalam segi termenologi adalah metode yang digunakan untuk mencari sebab ('illah) hukum bahasa dalam ilmu nahw (al-istidlal an-nahwi) baik langsung maupun tidak langsung, yang berujung pada suatu kesimpulan yang bersifat murni logis maupun bersifat alami (Mun'im, 1990, h. 213). Kelima, 'amil. 'Amil dalam ilmu nahw merupakan konsep yang secara nyata langsung dipelajari, meski itu pemula. 'Amil memiliki peran yang sangat dominan dalam keseluruhan konstruksi ilmu nahwu, khususnya dalam formulasinya seperti dikenal sekarang ini. 'Amil merupakan sokoguru dalam pembelajaran nahw. Praktik logika nahw merupakan logika dari 'Amil itu. Secara etimologi 'amil merupakan bentuk ism al-fa'il dari kata 'amila yang berarti "sesuatu yang bekerja". Tokoh yang kali pertama memperkenalkan 'amil adalah Imam Khalil. Adapun 'amil dalam konteks ilmu nahw adalah sesuatu yang menyebabkan atau mempengaruhi yang lain dari segi hukum atau $i^{\prime} r a b$ dalam suatu konstruksi ungkapan (Daif, 1986, h. 14). Sesuatu yang dimaksud di sini bisa berupa lafal atau makna yang dikirakirakan (tidak eksplisit dijelaskan. Dengan kata lain, dalam suatu konstruksi 'amil memiliki pengaruh secara nyata berupa harakat atau syakal dan atau huruf yang terdapat di akhir kalimat. 'Amil juga yang menentukan fungsi dalam suatu konstruksi misalnya musnad ilaih idan imusnad, mubtada' dan khabar dan seterusnya.

Keenam, ta'wil. Ta'wil Secara etimologi adalah mengira-ngira, menafsirkan dan merenung. Sedangkan secara terminologi ta 'wil berarti merubah zahir teks (lafal) dari posisi yang umum dipahami menuju posisi (makna) yang jarang dipahami. Dengan perubahan ini seolah-oleh makna itu meninggalkan zahir teks. Dalam kajian keislaman ta'wil merupakan salah satu metode penafasiran yang hasilnya diperdebatkan, terutama bagi kelompokkelompok literal-baca: tafsir lugawi. Atas dasar inilah ada yang memahaminya sebagai upaya menafsirkan ucapan yang maknanya berbeda-beda dengan disertai penjelasan yang diambil dari luar teks (Manzur, 1996, h. 264).

Ketujuh, istihsan yaitu meninggalkan metode qiyas yang dianggap membingungkan. Ada juga yang mendefiniskan istihsan sebagai pengkhususan 'illah. Secara umum istihsan adalah cara menyusun kaidah-kaidah yang dianggap baik oleh manusia tanpa dalil. Oleh Al-Anbari batasan baik adalah menurut para ulama dan bukan memberi batasan itu sendiri. Kedelapan, istishhab. Istishhab sebagaimana diungkapkan al-Anbari adalah mempertahanan kondisi lafal tetap pada asalnya ketika tidak ada dalal naql atau berdasarkan sama' tentang asal. Seperti diketahui perumusan kaidah bahasa Arab akan selalu terkait dengan konsep asal sebagi patokan utama. Apabila tidak sesuai dengan asal berarti ada pengecualian. Istishhab termasuk salah satu dalil ushul al-nahw yang diakui sebagai otoritatif (al-Anbari, 1964, h. 300). Istishhab memiliki empat kaidah, yaitu ashl al-wad' (asal pembuatan atau sumber), ashl-qa'idah (asal kaidah), al-'udul 'an al-ashl (perubahan dari asal) dan ar-radd ila al-ashl (kembali kepada asal) Hassan, 2000, h. 107). Para ulama mengamati, mencatat, 
mengaklasifikasi dan menginduksi hasil dari sama'. Berdasarkan hasil ini kemudian disusunlah kaidah-kaidah umum mengenai bahasa Arab (ashl al-qa'idah). Selain itu dalam nahw para ulama juga menyusun kaidahkaidah yang berbeda dengan kaidah asal (istishna' al-qaidah) atau bisa juga disebut kaidah cabang (al-qa'idah al-far'iyyah).

Dengan metode-motode di atas dirumuskanlah suatu kaidah atau teori-teori nahw atau dalam tradisi ilmu Syariah, nahw adalah fiqh kemudian ushul an-nahw adalah ushul al-figh. Pada kajian nahw sering memberikan contoh-contoh, yang sebelumnya dikasih kaidah dengan tujuan untuk memperjelasnya. Maka dengan dasar ini secara etimologi ada yang menyebut nahw dengan model atau contoh dari kaidah tersebut. Pengertian Ini juga tergambar dari asal kata nahw adalah naha yanhu nahwan yang mempunyai arti condong, cenderung, menuju dan bermaksud. Dalam bahasa Arab nahw merupakan bentuk mufrad dan bentuk jama'nya adalah anha yang berarti sama dengan, contoh dan seperti (Wher, 1980, h. 948). Secara terminologi Nahw adalah pengetahuan yang dengannya dapat diketahui posisi akhir kata baik dari mu'rab maupun mabninya. Belakangan definisi di atas dikritik para linguis Arab modern, di antaranya adalah ibrahim Anis. Menurutnya pembahasan nahw difokuskan pada posisi i'rab an sich telah mengabaikan hal-hal penting terkait susunan dalam kalimat bahasa Arab. Jika ini berlanjut terus menerus, bahasa Arab akhrinya bersifat sporadis dan tidak sitematis. Atas dasar ini Ibrahim Anis mendefinisikan nahw sebagai aturan penyusunan kalimat, penjelasan posisi setiap akhir kata dalam kalimat dan posisi kata dengan kata lain dalam kalimat sehingga menjadi sebuah kalimat yang sistematis dan memiliki pengertian yang utuh (as-Sa'idi, 1974, h. 9).

Adapun Nahw dalam bahasa Indonesia disebut sintaksis atau tata bahasa Indonesia. sintaksis berasal dari bahasa Yunani, suntattein, yang dibentuk dari sun artinya 'dengan', dan tattein artinya 'menempatkan'. Istilah suntattein secara etimologis berarti menempatkan bersama-sama kata-kata menjadi kelompok kata atau kalimat dan kelompok-kelompok kata menjadi kalimat (Suhardi, 2008, h. 31-32).

\section{Penyusunan an-Nahw Pedagogis dengan Dasar Ushul an-Nahw}

Dengan mengacu pada konsep linguistik edukasional sebagai salah satu pendekatan pendidikan bahasa yang bersifat koordinatifinterkonektif maka dalam proses pembelajaran bahasa Arab selain menggunakan landasan teori-teori pendidikan (asas nazhariyyat at-tarbawi) seperti kurikulum, silabus, materi, media, evaluasi dan metode pembelajaran juga harus dilandasi ilmu-ilmu bahasa Arab. Ini dikarenankan bahasa sebagai objek yang diajarkan akan selalu mempengaruhi proses pembelajaran. Bahkan tujuan pembelajaran bahasa sangat tergantung dari pemaknaan hakikat bahasa oleh para linguis (Parera, 1994, h. 6).

Dengan mengikuti Parera, pengaplikasian teori bahasa Arab agar memberikan kontribusi dalam pembelajaran bahasa Arab melalui tiga tahapan. Pertama, para linguis akan menjelaskan secara general hakikat bahasa yang akan diajarkan. Akan tetapi tidak menjawab apa yang akan diajarkan atau bagaimana butir-butir bahasa itu diajarkan. Untuk pembelajaran bahasa Arab, hakikat dan teori-teori bahasa Arab sudah dijelasakan para linguis Arab. Kedua, Pemilihan bahan atau isi silabus yang akan diajarkan kepada peserta didik dengan menyeleksi teori-teori bahasa general yang dilakukan oleh pendidik bahasa (Ibid, h. 1315). Dalam konteks pembelajaran bahasa Arab, para pendidik menyeleksi dengan meneliti teori-teori bahasa Arab murni yang dicetuskan linguis Arab untuk menemukan bahan atau isi yang khusus digunakan dalam pembelajaran bahasa Arab.

Dalam pemilahan teori-teori bahasa murni-seperti 'ilm nahw di atas, pendidik perlu mempertimbangkan dua kriteria pemilihan bahan atau isi silabus (Ibid, h. 1315). 1) Manfaat bagi peserta didik yang menyangkut keperluan kehidupan dengan bahasa itu. Dalam konteks pendidikan bahasa Arab, pendidik harus mengetahui psikolinguistis peserta didik tentang bahasa yang diajarkan. 2) Kesukaran bagi peserta didik menyangkut perbedaan bahasa pertama dengan dialek-dialek lain dalam bahasa itu (intralingual) dan perbedaan bahasa pertama dan kedua (interlingual). Salah satu kesukaran yang sering dialami peserta didik bahasa Arab adalah pengaruh dari bahasa ibu (Jawa atau Indonesia). Hal disebabkan pola pikir peserta didik dalam mengikuti pembelajaran sudah tersetting dengan struktur bahasa Indonesia sehingga dalam penyusunan kalimat Arab terpengaruh dengan struktur bahasa Indonesia (Setyawati, 2010, h. 54). Jadi di sinilah pentingnya analisa kontrastif (dirasah 
taqabuliyyah) antara bahasa Arab dengan bahasa Indonesia dalam memilih bahan dan isi silabus pembelajaran bahasa Arab untuk orang Indonesia (Yaqut, 1992, h. 7-12).

Ketiga, kegiatan pengajaran (pembelajaran) bahasa yang didasarkan atas dasar hasil dari pemilihan isi bahan atau silabus. Dalam pembelajaran bahasa ini juga perlu diperhatikan faktor linguistik, sosiolinguistik dan psikolinguistik serta teoriteori pendidikan. Selain itu tujuan dari tahapan ini adalah menjadikan semua unsurunsur pembelajaran seperti tujuan, materi, pendidik, peserta didik, metode, media, evaluasi, lingkungan dan lembaga harus bersifat pedagogis (Parera, 1994, h. 15). Artinya, dalam konteks pembelajaran bahasa Arab, unsur-unsur pembelajaran tersebut harus sesuai dengan dan untuk proses belajarmengajar bahasa Arab.

Unsur pembelajaran bahasa Arab yang paling signifikan dan perlu diperhatikan adalah tujuan (agrad ad-dirasiyyah) dan materi pembelajaran (al-maddah addirasiyyah). Karena, dalam paradigma linguistik edukasional yang menjadi pusat adalah tujuan dan materi. Tujuan pembelajaran yang dibreakdown menjadi materi adalah unsur yang menghubungkan antara pendidik dan peserta didik.

Dalam pembelajaran bahasa Arab khususnya nahw, materi yang diajarkan harus bersifat pedagogis. Pada tahapan aplikasi kedua, secara umum 'ilm an-nahw sudah diseleksi dengan tujuan pembelajaran, hanya saja belum bersifat sempurna. Artinya, penyusunan materi dengan prinsip-prinsip yang terdapat dalam ilmu pendidikan belum dilakukan. Untuk itu diperlukan teori untuk pengembangan materi nahw pedagogis agar menjadi aplikatif seperti kriteria dan prinsipprinsip penyusunan (usus wa munthalaqat) (Pateda, 1991, h. 59-64).

Kerangka aplikasi yang ditawarkan D.J. Parera di atas, tampak belum memadahi karena adanya generalisasi teori-teori bahasa, maka dibutuhkan operasionalisasi yang khusus digunakan dalam konteks linguistik dan pendidikan bahasa Arab, terutama pada tahap pemilihan. Ini karena, untuk melakukan pemilahan setidaknya pendidik harus mengetahui basis metodologi yang digunakan linguis Arab atau minimal alur dari basis penyusunan metodologi tersebut hingga menjadi nahw. Selain itu, teori-teori nahw klasik, terutama yang dipelajari di Indonesia adalah nahw yang dihasilkan sebagaimana diungkapan Muhammad Musthafa (2011) tidak hanya berdasarkan metode ilmiah, melainkan terpengaruh teologi dan filsafat (Alim, 2011 dan Afandi, 2008, h. 133-152).

Metodologi dalam menyusun teori-teori kebahasaan linguistik Arab bisa dilacak dari konsep 'ushul an-nahw. Meskipun Bahasa Arab hari ini berkembang pesat, namun secara umum metodologi penyusunannya tetap berpijak pada ushul an-nahw, bahkan beberapa linguis Arab modern yang cenderung liberal dan hanya menggunakan teori-teori Barat untuk menganalisis bahasa Arab secara tidak langsung juga menggunakan konsep dan term nahw hasil olah dari ushul anl-nahw. Di dalam 'ushul an-nahw diuraikan berbagai metode seperti sima' atau naql, ijma', qiyas, 'amil, ta'lil, ta'wil dan istishab. Lebih jauh, dengan metode-metode ini akan ditemukan basis epistemologinya.

Pengetahuan epistemologi dan metodologi di atas digunakan untuk mengetahui konstruksi bangunan teori linguistik Arab, mulai dari-meminjam istilah Goetz dan Lecomte (1984, h. 36)-grand theory, middle teory dan subtantif theory atau jika menggunakan istilah metode istishab yaitu ashl a-wad' (asal pembuatan), ashl al-qawaid (asal kaidah/teori), al-'udul 'an al-ashl (perubahan dari asal) dan ar-radd ila al-ashl (kembali ke asal) (Hassan, 1994, h. 107). Dari bangunan teori ini akan dibedakan teori-teori yang diperuntukan untuk bahasa itu sendiri yang bersifat deskriptif (washfi) dan bahasa yang bisa dimanfaatkan dalam konteks pembelajaran dengan norma dan kaidah tertentu (mi'yari). Bahkan pada tataran tertentu, pendidik mampu menyingkirkan teori-teori filosofis bahasa Arab yang tidak berguna dalam pembelajaran. Argumentasi ini mengandaikan bahwa, selain menguasai 'ilm an-nahw itu sendiri pendidik juga mampu merekontrusksi 'ilm an-nahw (Malawi, 2012, h. 211-225).

Berdasarkan argumentasi di atas secara operasional untuk menemukan nahw pedagogis akan dilakukan lima langkah tahapan. Pertama, analisis metode ushul annahw yang selama ini dikembangkan ulama klasik dalam menghasilkan nahw. Metode ushul an-nahw merupakan suatu metode yang bisa digunakan dalam rangka menghasilkan kaidah nahw di satu sisi dan bisa pula untuk melihat alur metodologis dalam menelurkan tata bahasa Arab.

Masing-masing metode ushul an-nahw mempunyai karakteristik dalam menghasilkan nahw. Seperti diketahui bahwa para ulama hanya berselisih pada metode ushul an-nahw 
ma'qul yaitu metode penyusunan teori nahw yang bersumber dari akal seperti qiyas, ijma', ta'lil, 'illah, ta'wil, istihsan dan istishhab dan sepakat pada metode ushul an-nahw manqul yaitu metode penyusunan teori nahw yang bersumber dari data bahasa yang berupa Alquran, hadis dan kalam Arab atau yang biasa disebut sima'. Dalam konteks penggunaan metode ma'qul inilah ranah teologi dan filsafat dari suatu kelompok mazhab masuk dan berkontribsi dalam menghasilkan nahw teologis-filosofis, yaitu teori nahw yang menggunakan logika teologi dan filsafat sehingga kurang mencerminan tata bahasa Arab yang dipakai secara umum, bahkan seolah-olah teori nahw itu berdiri sendiri di luar bahasa Arab. Seperti diketahui, kaidah nahw yang seharusnya sebagai alat dalam rangka mempermudah atau memahami Bahasa Arab justru menjadi ilmu sendiri yang dikaji. Ketika mengkaji nahw orang terjebak dan tidak bisa keluar dari "kubangan" nahw itu sendiri. Ini barangkali tidak menjadi masalah bagi yang concern di Ilmu bahasa Arab murni, namun bagi yang sekedar memposisikan nahw sebagai alat untuk belajar bahasa Arab menjadi problem krusial.

Metode sama' atau ada yang menyebut naql merupakan metode yang semua pakar linguis sepakat menggunakannya dalam rangka menyusun kaidah bahasa Arab. Kaidah-kaidah yang dihasilkannya pun hampir semua ulama sepakat memakainya. Artinya, kaidah-kaidah sama' adalah kaidah deskriptif dari relatitas bahasa orang Arab hasil konstruksi ulama. Dengan demikian, kaidahkadiah sama' kemungkinan bisa diaplikasikan dalam konteks pembelajaran. Alasannya, kaidah ini langsung bisa diterapkan dalam tindak komunikasi.

Berbeda dengan kaidah sama', kaidah dari hasil metode qiyas tidak semuanya bisa dipakai. Ini dikarenakan, metode qiyas adalah menyamakan dengan susuatu yang ada (sama). Qiyas digunakan ulama Basrah sebagai alternatif menyusun kaidah dikarenakan keterbatasan waktu dari Linguis sementara pengguna bahasa Arab sangant banyak dan luas. Akhirnya, disusunlah kadiahkaidah umum, yang bisa jadi dalam praktik berbahasa orang Arab tidak ditemukan. Contohnya adanya mashdar simai' dan mashdar qiyasi. Yang pertama merupakan hasil sama', sedangkan yang kedua adalah konstruksi dari ulama yang menyamakan dengan kaidah umum yang disusun sebelumnya.
Menurut Ibn Madha' dalam penyusunan kaidah nahw penggunaan qiyas diperbolehkan sepanjang disertai bukti teks atau data-data sama' yang nyata. Apabila tidak ditemukan, kaidah hasil qiyas tidak dapat diterima, bahkan bila perlu ditolak. Khusus, qiyas aqli Ibn Mada'menolaknya karena linguis Arab dianggap kurang cermat dengan membawa sesuatu kepada sesuatu yang lain dengan tanpa adanya hubungan atau keterkaitan yang jelas dan konkrit dalam mengqiyaskan dua hal. Ibn Mada' menjelaskan:

"Orang Arab adalah bangsa yang pintar, bagaimana mungkin menyamakan sesuatu dengan sesuatu yang lain, dan menyamakan hukum sesuatu itu pada sesuatu yang lain, sementara sebab hukum asal tidak ditemukan dalam cabang? Jika di antara para linguis Arab ada yang melakukan seperti ini, berarti "bodoh" dan tidak diterima. Mengapa mereka menghubungkan sesuatu yang tidak diketahui sebagian mereka kepada orang Arab? Ini semua karena para linguis tidak mengqiyaskan sesuatu dan memberlakukan hukumnya kecuali jika sebab hukum asal ditemukan pada cabang" (Mada', 1974, h. 156).

Metode lain yang kaidahnya harus diseleksi adalah kaidah yang dihasilkan dari ta'wil. Ini dikarenakan dalam berbahasa, sesuatu tidak ditampakkan adalah hal yang lumrah. Ta'wil mengandaikan tatabahasa dalam tulisan sementara dalam konteks komunikasi adalah tergantung konteks baik internal maupun ekternal. Membuang atau menyembunyikan hal yang sudah maklum adalah lumrah, bahkan jika ditampakkan justru akan menggangu komunikasi. Yang perlu dicatat dalam konteks ini adalah kaidahkaidah yang dihasilkan ta'wil tepat digunakan dalam maharah kitabah, namun tidak untuk kalam dan istima: Mayoritas para linguis Arab modern yang dipengaruhi Barat juga menolak kaidah yang dihasilkan dari ta'wil. Para pemakai ta'wil dianggap mengada-ada terhadap beberapa teks yang seharusnya tidak membutuhkannya (Al-Mathlabi, 1986, h. 92).

Kaidah yang sama dengan ta'wil adalah kaidah yang dihasilkan metode ta'lil, apalagi yang dikembangkan mazhab Andalusia mengenai 'illah pertama dan kedua. Kaidah ini jelas menjadi sesuatu yang di luar bahasa itu sendiri. Kaidah nahw terlampau jauh membahas konsep yang merupakan ilmu tersendiri, bukan nahw sebagai alat. Misalnya dalam kasus "khabar", kaidah nahw Basrah merumuskan untuk membaca rafa', maka 
nahwu Andalusia akan memperluas dengan alasan kenapa di baca rafa' kemudian diberilah alasan-alasan (ta'lilat) yang sangat panjang. Pertanyaan-pertanyaan lanjutan "kenapa, mengapa" ini disebut 'illah pertama, kedua dan seterusnya (Daif, 1976, h. 239).

Jika dianalisis secara mendalam metode ta'wil, ta'lil dan qiyas merupakan metode yang digunakan untuk memperkuat kehadiran metode 'amil. Artinya, kemunculan ketiga metode ini dilatarbelakangi adanya 'amil dalam sturktur bahasa Arab. Menurut Sibawaih, 'amil merupakan konsep yang dihadirkan untuk menjelaskan perubahanperubahan sturktur kalimat bahasa Arab. Perubahan dalam kalimat atau cara membaca akhir kata selalu dikaitkan dengan 'amil yang mendahuluinya. Sangat vitalnya 'amil ini maka bangunan ilmu nahw terletak padanya. Jika 'amil diruntuhkan maka runtuhlah teori-teori nahw yang sudah dibangun selama ratusan tahun. Padahal 'amil sendiri bukan salah satu unsur bahasa, melainkan konsep yang ada di luar bahasa yang diciptakan linguis Arab klasik. Pada awalnya kemunculan 'amil adalah sebagai konsep umum yang bisa dijadikan sebagai dasar fenomena-fenomena bahasa Arab secara umum.

Atas dasar di atas, kaidah-kaidah yang disusun berdasarkan 'amil juga perlu dianalisis ulang. 'Amil dalam bahasa Arab sangat dibutuhkan sebagai pemetaan konstruksi tatabahasa. Maksud dari pengertian ini, kaidah-kaidah deskriptif yang dicipatakan ulama klasik adalah kaidah yang sudah mapan. Dengan begitu, kaidah ini bisa diikuti hanya saja konsep-konsep lanjutan dalam rangka mendukung teori 'amil tidak semuanya dipakai. Yang didahulukan adalah level pertama ('illah pertama) yang berada dipermukaan karena inilah sejatinya nahw sebagai alat yang mempermudah pembelajaran bahasa Arab.

Selain itu, metode ta'wil atau ada yang menyebut taqdiri juga disebabkan 'amil (ma'nawi) yang tidak tampak dalam sturktur. Kaidah-kaidah yang dihasilkan seperti ini juga harus dihindari dalam pembelajaran karena tidak dibutuhkan dalam menerangkannya. Orang Arab tidak memerlukan hal-hal yang semacam itu.

Argumentasi tersebut sejalan dengan pendapat Ibn Mada' yang menjelaskan bahwa konsep 'amil yang tidak merusak bahasa Arab diperbolehkan diikuti hanya saja kebanyakan amil menurutnya justru mengacaukan bahasa Arab. Tambahnya, nahw tidak berjalan sesuai wataknya, padahal watak nahw adalah alat bukan Ilmu itu sendiri. Konskuensi dari penolakan 'amil ini adalah struktur yang dibahasa dalam nahw adalah yang tampak dipermukaan dan tidak ada pembahasan menganai saling mempengaruhi satu kata dengan kata lain dalam kalimat, melainkan hanya menjelaskan fungsi dan peran di dalamnya. Konskuensi lain yaitu konsep itrab sepert rafa' nashb, jarr dan jazm bisa diperingkas dengan tanda-tanda harakat saja seperti dummah dan kasrah (Musa, 1992, 40$50)$.

Adapaun metode ishtishab dalam konteks ini bisa digunakan sebagai cara mengklasifikasi dan memperioritaskan kaidah-kaidah 'ilm nahw yang bisa digunakan sebagai pembelajaran. Dengan metode ini dapat dilihat mana yang signifikan untuk nahw pembelajaran. Untuk teori pertama, ashl al-wad' (asal pembuatan atau sumber) dalam konteks bahasa Arab modern perlu ada perluasan daerah karena bahasa berkembang dengan cepat maka penelitian mengenai bahasa harus dikukan sesering mungkin. Realitas sekarang, bahasa Arab mengalami perkembangan baik dalam kosa kata maupun sturktur. Sementara teori kedua ashl-qa'idah (asal kaidah) digunakan untuk mengklasifikasi kaidah-kadaih yang sifatnya sangant urgen dalam struktur, kalaupun ada kaidah-kaidah asal namun dihasilkan dari metode ta'lil, qiyas, ta'wil dan istihsan perlu dihindari atau jika terpaksa dipakai harus dengan skala yang kecil dan dalam praktikknya ditaruh ditingkatan atas. Khusus kaidah yang dihasilkan dari teori ketiga dan keempat al'udul 'an al-ashl (perubahan dari asal) dan arradd ila al-ashl (kembali kepada asal) ini untuk pembelajar pemula harus dihindari, sementara untuk yang tingkatan lanjut bisa dipakai dengan dengan syarat sebagaimana teori kedua.

Kedua, Penyisihan terhadap kaidahkaidah yang dihasilkan dari metode yang dianggap kurang relevan dalam pembelajaran bahasa Arab. Ini sebagaimana diungkapkan dalam penggunaan metode ishtishab di atas. Kaidah-kaidah yang bisa digunakan adalah kaidah-kaidah yang dihasilkan dari ashlqa'idah (asal kaidah). Inipun harus diseleksi dengan pembuktian bahwa itu berlaku secara umum dalam Orang Arab dan tidak didasarkan pada metode ta'lil, qiyas ataupun ta'wil. Sedangkan kaidah yang dihasilkan dari kedua teori tersisa dari istishhab tidak digunakan melainkan untuk peserta didik tingkatan atas. Yang perlu diperhatikan dalam penysisihan ini adalah asumsi bahwa kaidah 
ini nantinya akan digunakan dalam pendidikan, sehingga kaidah yang jauh dari realitas bahasa harus disingkirkan. Penyingkiran inipun harus hati-hati, karena diperlukan pemetaan terlebih dahulu dengan ilmu nahw itu sendiri dengan memisah antara teori cabang dan teori asal sebagaimana ditinjau dari teori istishab. Kebanyakan teori yang akan disisihkan adalah teori-teori yang berbentuk cabang, sedangkan asal adalah kebalikannya. Namun demikian beberapa kaidah yang berbentuk asalpun harus direkonstruksi. Cara yang mungkin sederhana adalah dengan bantuan Lingusitik modern, dimana struktur ilmu nahw bisa dibaca dengan kacamata objektif.

Ketiga, Klasifikasi Unsur-Unsur deskriptif-pedagogis Nahw. Dengan dasar analisis atau peninjauan ulang metode di atas secara umum nahw bisa didefinisikan sebagai ilmu yang mengkaji hubungan antar kata dalam satu kontruksi kalimat. Jadi dalam ilmu ini kata merupakan modal awal dan kalimat adalah akhir dari pembahasannya atau membincangkan hubungan kata dengan kata lain dalam suatu ujaran. Jadi dalam kajian nahw kata merupakan satuan terkecil, sedangkan di sharf merupakan satuan terbesar. Struktur 'ilm an-nahw Arab (organisasi berbagai unsur bahasa yang masing-masing merupakan pola bermakna di dalam suatu kesatuan nahw) bisa diklasifikasikan empat yaitu fungsi sintaksis, kategori sintaksis, peran sintaksis dan alat sintaksis bahasa Arab.

1) Fungsi Sintaksis. Fungsi sintaksis adalah semacam kotak-kotak atau tempattempat dalam struktur sintaksis yang kedalamannya akan diisikan kategori-kategori tertentu. Kotak-kotak tersebut bernama musnad ilaih atau subjek (Mi), musnad atau predikat (M), maf 'ul bih atau objek (Ma), fudlah atau komplemen (Fu). Dengan demikian, subjek atau musnad ilaih dalam bahasa Arab bisa berupa mubtada', fa'il, naib al-fa'il, ism inna, ism kana. Predikat atau musnad berupa khabar, fil, khabar inna, khabar kana. Objek dalam bahasa Arab adalah maf'ul bih. Keterangan atau dalam bahasa disebut fudlah adalah maf'ul fih, maf'ul muthlaq, maf'ul li ajlih, maf'ul ma'ah dan hal.

Dalam konteks pembelajaran bahasa Arab cukup dengan menyebut musnad ilaih, musnad, maf'ul dan fudlah saja, meskipun di dalamnya nanti ditemukan term atau konsep yang berbeda-beda. Ini merupakan konsep nahw deskriptif yang hanya berbicara atas bahasa itu sendiri. Mengacu argumentasi di atas, konsep-konsep yang mengisi fungsi sintaksis pada level kedua merupakan konsep ulama klasik yang tujuan awalnya adalah memudahkan, namun apabila ini dibahas secara mendetail justru fungsi nahw sebagai alat akan tereduksi karena konsep-konsep ini di luar bahasa. Dalam fungsi nahw sintaksis di atas keempat unsur bisa lengkap atau hanya terdiri dua unsur saja. Kedua fungsi itu adalah musnad ilaih dan musnad harus selalu ada dalam kalimat karena keduanya saling berkaitan. dalam hal ini bisa dikatakan, bahwa munad ilaih adalah bagian kalimat yang menandai apa yang dinyatakan oleh pembicaraan, sedangkan musnad adalah bagian klausa yang menandai apa yang dinyatakan oleh pembicaraan mengenai musnad (Chaer, 2009, h. 20-21).

2) Kategori sintaksis adalah jenis atau tipe kata (kalimah) atau frase (tarkib) bahkan klausa (jumlah) yang menjadi pengisi fungsifungsi sintaksis. Kategori sintaksis yang terkait dengan kata adalah ism atau nomina (I), fi'l atau verba (F), washfi atau adjektiva (W), darfi atau adverbia (D), 'adai atau numeralia (A), sibh al-jumlah atau preposisi (Sb), Athaf atau konjungsi (At) dan pronominal (Pron). Dalam hal ini ism, fi'l dan washf merupakan kategori utama; sedangkan yang lain merupakan kategori tambahan.

Selain kata, pengisi fungsi sintaksis dapat pula berupa frase. Tarkib atau frase adalah gabungan kata yang belum bersifat predikatif, tidak melebihi batas fungsi sintaksis dalam kalimat, bisa diganti dengan satu kata, dan tidak melebihi batasa klausa. Dalam bahasa Arab disebut tarkib (T) atau 'Ibarah yaitu gabungan dari unsur-unsur yang saling terkait dan menempati fungsi tertentu dalam kalimat, atau suatu bentuk yang di dalam struktur sintaksis disamakan dengan kata tunggal, dengan pengertian lain, gabungan kata tersebut bisa diganti dengan satu kata (ism/fi't) (Badri, 1986, h. 28). Jadi, Frase adalah kontruksi kebahasaan yang terdiri dari dua kata/lebih, hubungan antar kata dalam kontruksi ini tidak predikatif dan dapat diganti dengan satu kata.

Dengan demikian pola pula frase nominal atau tarkib ism (TI) yang terdiri dari ism, di samping kata verba ada pula frase verbal atau tarkib yang ada unsur fi'l (TF), dan di samping ada kata adjektiva ada pula frase adjectival atau tarkib shifah (TS), dan seterusnya. Secara formal kategori I atau TI mengisi fungsi Mi dan atau Ma pada kalimat verbal; bisa juga mengisi fungsi $M$ pada kalimat nominal. Kategori $\mathrm{F}$ atau $\mathrm{TF}$ secara 
formal mengisi fungsi M pada klausa verbal, dan kategori I atau TI mengisi fungsi M pada klausa adjectival. Lalu, kategori A menjadi bagian pembentuk TI atau TA; dan kategori Preposisi menjadi bagian dari TS. Sementara itu kategori Konjugasi yang bersifat koordinatif menjadi penyambung intrafrase atau antarklausa; sedangkan yang bersifat subordinatif menjadi penyambung intrakalimat atau antarkalimat (Chaer, 2009, h. 27-28).

Kategori juga bisa diisi klausa manakala dalam suatu kalimat majemuk. Klausa dalam bahasa Arab disebut jumlah (J) adalah satuan garamatik berupa kelompok kata yang minimal mengandung unsur $\mathrm{M}$ dan $\mathrm{Mi}$ yang mempunyai potensi menjadi kalimat, belum mempunyai makna yang utuh dan tidak diberi intonasi akhir. Klausa berada dalam kalimat majemuk dan jika dikeluarkan dari kalimat itu akan menjadi kalimat tersendiri. Hanya saja, klausa tidak bisa dilepas dari suatu kalimat karena ada yang menghubungkan dengan kata sebelum/sesudahnya. Untuk membedakan dengan kalimat, karena dalam taradisi nahw klasik jarang dibedakan, di dalam bahasa Arab, klausa diterjemahkan jumlah, sedangkan kalimat adalah kalam. Kalimat dalam bahasa Arab sendiri dibagi menjadi tiga, yaitu kalam basit (kalimat tunggal), kalam tarkibi (kalimat majemuk bertingkat) dan kalam murakkab (kalimat majemuk setara).

3) Peran Sintaksis. Peran sintaksis adalah hubungan antara kategori pengisi fungsi $\mathrm{M}$, baik berkategori $\mathrm{F}$ maupun bukan, dengan pengisi fungsi-fungsi lain. Peran sintaksis menurut Verhaar adalah makna yang dikandung dari unsur-unsur fungsi sintaksis atau segi semantis dari peserta-peserta verb (F). Unsur peran ini berkaitan dengan makna gramatikal atau sintaksis. Dengan adanya peran ini dapat diketahui makna dari masingmasing unsur fungsional tersebut. Artinya, unsur $\mathrm{M}$ atau $\mathrm{V}$ merupakan unsur terpenting dalam peran sintaksis. Makna unsur pengisi Mi adalah pelaku, alat, sebab, penderita, hasil, tempat, penerima, pengalaman, dikenal dan terjumlah. Sedangkan makna peran pengisi $\mathrm{M}$ adalah perbuatan, keadaan, keberadaan, pengenal, jumlah dan pemerolehan. Adapun makna Ma adalah penderita, penerima, tempat, alat dan hasil. Makna keterangan atau $\mathrm{Fu}$ adalah tempat, waktu, cara, penerima, peserta, alat, sebab, keseringan, perbandingan dan perkecualian (Putrayasa, 2014, h. 91-96). Khusus musnad juga bisa mempunyai makna lain seperti proses, kejadian, Pemilikan, identitas, kuantitas. Sedangkan Mi dan Ma bisa ditambahi makna seperti sasaran, penanggap, pengguna, penyerta, jangkauan dan ukuran (Chaer, 2009, h. 29-33).

Dengan argumentasi ini konsep 'amil yang menjadi metode bahasa Arab bisa ditinjau ulang karena hubungan antar unsur struktur sintaksis ini tidak secara langsung dan sifatnya tidak ada yang dipengaruhi dan mempengaruhi melainkan keduanya saling mempengaruhi (sama-sama aktif). Satu unsur ada namun unsur lain tidak maka struktur tidak ditolak. Mi misalkan, tidak akan mempengaruhi $\mathrm{M}$ karena jika $\mathrm{M}$ tidak ada maka Mi pun menjadi tidak ada. Ini berbeda dengan argumentasi ulama klasik yang mengatakan bahwa Mi adalah 'amil (yang mempengaruhi) dan $\mathrm{M}$ adalah ma'mul (yang dipengaruhi). Karena asumsinya adalah sesuatu yang mempengaruhi bisa berdiri sendiri tanpa harus menghadirkan sesuatu yang dipengaruhi. Padahal 'amil tidak akan disebut 'amil manakala tidak ada ma'mul.

Dengan bahasa sederhana fungsi sintaksis di atas merupakan hubungan yang sudah semestinya dalam konstruksi kalimat yang bisa dijelaskan secara mandiri dari masing-masing fungsi itu. Konsekuensi logis dari ini maka akan memunculkan rekonstruksi i'rab (reksi). I'rab dalam tradisi ulama klasik dibagi menjadi empat, yaitu rafa', nashb, jarr dan jazm. Dari keempat ini akan memiliki tanda-tanda baik harakat (vokal) maupun harf (kononan) yang berbeda-beda.

Keempat i'rab di atas bisa saja ditiadakan karena keempat ini hanyalah konsep yang dicipatakan ulama klasik guna mempermudah pemetaan tanda i'rab. Keempatnya tidak ada dalam bahasa Arab itu sendiri. Yang ada dalam bahasa Arab adalah tanda-tanda i'rab. Ketika menganalisis kalimat bahasa Arab, tanpa menggunakan konsep keempat ini pun bisa dilakukan. Misalnya Mi yang berkategori ism mufrad konsonan terahir dibaca dummah. Contoh seperti ini lebih simpel dan aplikatif dalam pembelajaran. Bahkan dengan mengikuti pendapat Ibrahim Musthafa, tanda-tanda ini kurangi menjadi 2, yaitu dammah dan kasrah. Dammah merupakan tanda i'rab yang masuk dalam tarkib isnadi kecuali ism inna dan khabar kana. Sedangkan tanda i'rab kasrah hanya diperuntukan untuk kategori tarkib atau frasa idafi baik dalam bentuk ism maupun zharafmazhruf atu jar-majrur. Sementara fathah tidak termasuk tanda i'rab karena tidak menunjukkan makna apapun, kecuali orang Arab lebih suka mengunakan fathah dibanding harakah lain dikarenakan lebih ringan. Ini juga 
sekaligus menolak tanda i'rab yang sifatnya far'iyyah yaitu harf $y a^{\prime}$, waw atau alif. Kalaupun dalam beberapa kasus seperti $a s m a^{\prime}$ as-sittah atau jam' muzhakar Salim ada yang menggunakan huruf, ini merupakan isyba' yaitu pemuasan atau pemantapan semata. Ini bisa diketahui dari harakat yang melekat pada huruf akhir dalam kata. Semuanya mu'rab dengan tanda dummah dan kasrah karena sebagai idafi (Mushthafa, 1972, h. 78).

4) Alat sintaksis. Dalam ujaran bahasa Arab terdapat seperangkat aturan yang mengatur deretan kata-kata yang membentuk kalimat konstruksi sintaksis itu. Perangkat kaidah ini disebut alat sintaksis atau bisa juga disebut pola kalimat. Alat sintaksis merupakan bagian dari-meminjam bahasa chomsky- komptensi penutur untuk dapat menentukan apakah urutan kata, bentuk kata, dan unsur lain yang terdapat dalam ujaran berterima atau tidak. Alat sintaksis itu adalah urutan, bentuk kata, intonasi dan partikel atau kata tugas. Dalam kajian bahasa Arab yang paling dominan adalah urutan fungsi sintaksis yang kebanyakan dipengaruhi bentuk kategori kata yang ada pada $\mathrm{M}$.

Keempat, Membandingkan unsur nahw dengan gramatika Bahasa Indonesia. Langkah membandingkan ini dalam kajian kinguistik edukasional disebut dengan analisa kontrastif. Secara etimologi Kontrastif $\rightarrow$ Contrastive $\rightarrow$ to contras artinya berbeda atau bertentangan. Dalam "The American College Dictionary": menempatkan dalam oposisi atau pertentangan dengan tujuan memperlihatkan ketidaksamaan, memperbandingkan dengan jalan memperhatikan pebedaan-perbedaan. Sementara analisis: penguraian suatu pokok atas berbagai bagiannya dan penelaahan bagian itu sendiri serta hubungan antarbagian untuk memperoleh pengertian yang tepat dan pemahaman arti keseluruhan. Pendapat Djardjowidjojo, yang menyatakan bahwa analisis kontrastif adalah cabang ilmu bahasa yang tugasnya membandingkan secara sinkronik dua bahasa sedemikian rupa sehingga kemiripan-kemiripan dan perbedaan-perbedaan antara kedua bahasa itu bisa dilihat (Djardjowidjojo, 1978, h. 27). Sementara itu Kridalaksana mendefinisikannya sebagai metode sinkronis dalam analisis bahasa untuk menunjukkan persamaan dan perbedaan antara bahasabahasa atau dialek-dialek untuk mencari yang dapat diterapkan dalam masalah praktis, seperti pengajaran bahasa dan terjemahan" (Kridalaksana, 1984, h. 12).
Berdasarkan beberapa pendapat tersebut analisa kontrastif dimaknai sebagai suatu aktivitas linguistik-sinkronik yang bertujuan untuk menghasilkan tipologi dua bahasa (B1\&B2) yang kontras dan tidak serumpun baik dari unsur, sistem dan budaya kedua bahasa tersebut, sehingga hasilnya dapat digunakan dalam kepentingan praksis yang berkaiatan dengan kebahasaan, seperti pembelajaran bahasa ke2, penterjemahan, patologi bahasa, leksikografi.

Menurut teori ini orang cenderung untuk mengalihkan pola-pola struktur bahasa pertama ke pola-pola struktur bahasa kedua. Kaum behavioris berpandangan bahwa kesalahan berbahasa terjadi karena adanya transfer negatif atau dalam bahasa sosiolinguistik disebut interferensi. Maksudnya penggunaan sistem bahasa pertama dalam berbahasa kedua adalah hal yang tabu, sebab sistem bahasa pertama berbeda dengan bahasa kedua. Perbedaan sistem itu dapat dijelaskan dengan membandingkan bahasa pertama dengan bahasa kedua (Nurhadi, 1995, h. 240).

Dalam konteks tulisan ini analisa kontrastif difungsikan untuk membuat semacam sistematisasi nahw agar sesuai bisa digunakan di Indonesia. Sejalan dengan teori di atas bahwa bahasa Indoensia "mengganggu" proses memahami bahasa Arab yang dilakukan peserta didik. Ini dikarenakan peserta didik akan menjadikan bahasa indonesia sebagai acuan dalam berbahasa Arab. Analisa kontrastif berusaha meminimalisir transfer atau interferensi bahasa Indonesia ini. Dalam konsepnya jika teori atau kaidah bahasa indonesia sama maka akan mudah, jika tidak sepadan akan cukup mudah dan jika timpang akan sulit. Dasar ini dikoneksikan dengan prinsip-prinsip pembelajaran bahwa belajar yang baik adalah dimulai dari mudah ke sulit dan dari sederhana menuju kompleks. Dengan begitu seluruh kompenen bahasa Arab dan Indonesia sebelum disajikan menjadi materi pelu diperbandingkan terlebih dahulu. Kiadahkaidah yang sama didahulukan dan yang beda diakahirkan.

Kelima, menyusun bahan ajar pokok $n a h w$ pedagogis. Penentuan tujuan kemahiran berbahasa sehingga memunculkan kaidah. Untuk menyusun bahan ajar nahw pedagogis dilakukan lima tahapan langkah. 1) Berdasarkan analisa di atas unsur-unsur nahw pedagogis yang bisa menjembatani antara bahasa Arab dan Indonesia adalah musnad ilah, musnad, maf'ul bih dan fudlah. Ini 
merupakan unsur dari fungsi nahw pedagogis. 2) Adapun untuk kategori nahw pedagogis adalah kalimah (kata) yang terdiri dari fi'il; ism dan harf, tarkib (frasa) yang terdiri dari tarkib na'ti, taukidi, 'athfi (koordinatif) dan badali (apositif) ditambah frasa zharfi (adverbia), syibh al-jumlah (preposisi), manfi (negasi), syarthi, tanfis, tauqitat, 'adadi, nida'i, isyari, maushuli, tamyizi, mashdari maushuli, ikhtishashi dan istishna; dan jumlah (klausa) berupa jumlah fi'iliyyah dan ismiyyah. 3) Dari unsur-unsur nahw ini dan disertai pertimbangan analisa kontrastif, pola yang bisa digunakan, dari rendah menuju tinggi nahw pedagogis adalah

Tabel 1. Pola Nahw Pedagogis dari Rendah Menuju

\begin{tabular}{|c|c|c|}
\hline \multicolumn{3}{|c|}{ Tinggi } \\
\hline No & Pola & Contoh \\
\hline 1. & $\mathrm{Mi}+\mathrm{M}$ & الب ذكي \\
\hline 2. & $\mathrm{Mi}+\mathrm{M}+\mathrm{Fu}$ & الطالب يبكى في الفصل \\
\hline 3. & $\mathrm{Mi}+\mathrm{M}+\mathrm{Ma}$ & الطالب يدرس الّرس \\
\hline 4. & $\mathrm{Mi}+\mathrm{M}+\mathrm{Ma}+\mathrm{Fu}$ & تمامالب يدرس الدرس \\
\hline 5. & $\mathrm{Mi}+\mathrm{Ma}+\mathrm{M}$ & الطالب الدرس بدرس \\
\hline 6. & $\mathrm{Mi}+\mathrm{Ma}+\mathrm{M}+\mathrm{Fu}$ & تمامالب الدرس يدرس \\
\hline 7. & $\mathrm{M}+\mathrm{Mi}$ & يبكى الطالب \\
\hline 8. & $\mathrm{M}+\mathrm{Mi}+\mathrm{Fu}$ & يبكي الطالب في الفصل \\
\hline 9. & $\mathrm{M}+\mathrm{Mi}+\mathrm{Ma}$ & يقر أ الطالب القران \\
\hline 10. & $\mathrm{M}+\mathrm{Mi}+\mathrm{Ma}+\mathrm{Fu}$ & المسجدا الطالب القران في \\
\hline 11. & $\mathrm{M}+\mathrm{Ma}+\mathrm{Mi}$ & يقر ا القران الطالب \\
\hline 12. & $\mathrm{M}+\mathrm{Ma}+\mathrm{Mi}+\mathrm{Fu}$ & المسرجد القران الطالب في \\
\hline
\end{tabular}

Kedua belas pola di atas yang umum digunakan dalam bahasa Indonesia adalah 1-6 dengan pola aktif. Pola atau kaidah lima belas ini merupakan pola umum yang bisa digunakan di semua level pendidikan. Namun demikian, untuk penjenjangan, pola di atas perlu dipertimbangan perbedaan antara pola bahasa Arab dan Indonesia. Pola yang ada di Indonesia adalah 1-4, sehingga ini mudah bagi peserta didik Indonesia. Sementara pola 5-12 tidak ditemui di bahasa Indonesia, sehingga sulit. Khusus pola 5-6 merupakan pola jumlah ismiyyah hanya saja, dalam bahasa Indonesia Ma tidak boleh mendahului MI. Dengan demikian pola pertama adalah $1-4$, sedangkan pola lanjutannya adalah 5-12 secara berurutan. Untuk jenjang lanjut dalam bahasa Arab juga mengenal pola Ma berjumlah 2 dan $\mathrm{F}$ berjumlah 3. Jika ini dipakai maka akan ada tambahan 24 pola.

4) guna menyusun pola itu agar berjenjang (dari rendah menuju kompleks) juga harus dipertimbangkan kategori nahwnya (kata atau frasa atau klausa yang mengisi fungsi dari pola itu). Prinsip dasar untuk menyusun pola dasar lanjutan adalah ism didahulukan dari pada fi'l, kalimah (kata) didahulukan daripada tarkib (frasa), tarkib ismi au al-harf (frasa kata benda atau kata penghubung) lebih didahulukan daripada tarkib fi'li (frasa kata kerja), jumlah ismiyyah (klausa yang diawali kata benda / frasa kata benda atau kata penghubung) didahulukan daripada jumlah fi'liyyah (klausa yang diawali kata kerja). Prinsip ini berpedagang bahwa bahasa Indonesia tidak mengenal jenis kelamin (muzakkar atau muannats dan jumlah (persona dalam kata benda dan subjek dalam kata kerja) sementara bahasa Arab mengenal itu keduanya. Sehingga dibutuhkan analisa dengan melihat kesederhanaan dari kata itu. Khusus kata sambung sifatnya tetap baik dalam bahasa Arab maupun Indonesia, sehingga ini harus didahulukan. Kemudian untuk kata benda lebih didahulukan karena hanya terkena jenis $(2 ;$ muzakkar dan muannas) dan jumlah (3; mufrad, musanna dan jama'). Sedangkan kata keja terkena 14 baik jenis maupun jumlah sebagaimana yang dalam tashrif lugawi (infleksi).

Adapun penjenjangan selanjutnya adalah klausa. Untuk pembahasan klausa sebenarnya sudah include di pembahasan pola-pola sebelumnya, hanya saja harus dijelaskan dalam konteks kalimat. Penjenjangan kalimat sendiri dimulai dari kalam basith (kalimat tunggal)-sebagaimana di atas-dilanjutkan kalam tarkibi (kalimat majemuk bertingkat) dan diakhiri kalam murakkab (kalimat majemuk setara). Prinsip penyusunannyapun memiliki kesamaan dengan prinsip di frasa. Khusus kalimat tunggal sebenarnya sudah include dengan pembahasan frasa sebelumnya. Jadi dalam penjenjangan kalimat ini tunggal mengikuti alur sebelumnya. Kalam tarkibi dalam bahasa Arab setidaknya dibagi menjadi dua, yaitu yang teridiri dari klausa bebas dan klausa terikat; dan klausa terikat dan klausa bebas. Perhatikan contoh di bawah ini

Tabel. 2. Kalam Tarkibi

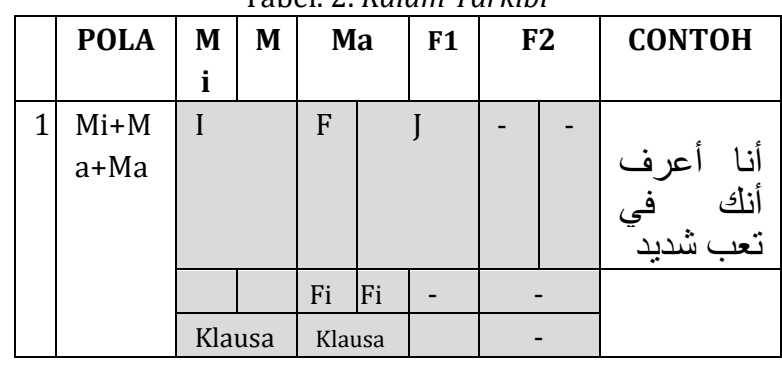




\begin{tabular}{|c|c|c|c|c|c|c|c|}
\hline & & \multicolumn{2}{|c|}{ Terikat } & Bebas & & & \\
\hline \multirow[t]{4}{*}{2} & \multirow{4}{*}{$\begin{array}{l}\mathrm{Mi}+\mathrm{M} \\
+\mathrm{F}\end{array}$} & I & $\mathrm{F}$ & - & $\mathrm{Ti}$ & $\mathrm{J}$ & \multirow{4}{*}{ 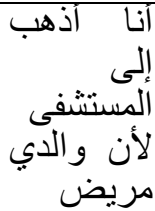 } \\
\hline & & & & & & $\mathrm{Ti}$ & \\
\hline & & \multirow{2}{*}{\multicolumn{2}{|c|}{$\begin{array}{l}\text { Klausa } \\
\text { Bebas }\end{array}$}} & & & \multirow{2}{*}{$\begin{array}{l}\text { Klausa } \\
\text { terikat }\end{array}$} & \\
\hline & & & & & & & \\
\hline
\end{tabular}

Ket: Mi: Musnad ilaih, M:musnad, Ma: maf'ul bih, F: fudlah, I: ism, F: fi'l, Ti: tarkib Ism/harf, Tf: takib fi'l dan J: jumlah.

Pada tabel 3, pola pertama $\mathrm{Mi}+\mathrm{Ma}+\mathrm{M}$ yang berkategori klausa terikat berada pada adalah $\mathrm{Mi}+\mathrm{M}$ dan klausa terikat terdapat pada Ma. Sedangkan pada pola $\mathrm{Mi}+\mathrm{M}+\mathrm{F}$ klausa terikat adapada $\mathrm{F}$ dan klausa bebas ada pada $\mathrm{M}+\mathrm{Mi}$. Ini merupakan pola awal yang bisa dikembangkan sebagaimana pada kalimat tunggal. Bisa jadi kalimat bebas ada pada $\mathrm{M}$ atau Mi atau Ma bahkan F. Dalam kasus bahasa Arab yang sangat komplek bisa sangat memungkinkan klausa ada pada keempat fungsi ini secara bersamaan dengan dua model sebagaimana di atas.

Adapun kalam murakkab merupakan kalimat majemuk yang memiliki dua klausa bebas yang biasanya digabung oleh frasa 'athfi (bisa berbentuk harf atau ism+harf). Berikut contohnya.

Tabel. 3. Kalam Tarkibi

\begin{tabular}{|c|c|c|c|c|c|c|c|c|c|}
\hline POLA & $\mathbf{K}$ & \multicolumn{4}{|c|}{ M } & Mi & Ma & F1 & F2 \\
\hline $\begin{array}{c}\mathrm{M}+\mathrm{Mi} \\
+\mathrm{Fi}+ \\
\mathrm{F} 2\end{array}$ & 1 & \multicolumn{4}{|c|}{$\mathrm{J}$} & I & - & $\mathrm{Ti}$ & I \\
\hline $\mathrm{M}+\mathrm{Mi}$ & 2 & \multicolumn{3}{|c|}{$\begin{array}{c}\mathrm{J} \\
(\mathrm{Mi})\end{array}$} & $\begin{array}{c}\text { I } \\
\text { (M) }\end{array}$ & & & & \\
\hline $\begin{array}{c}\mathrm{M}+\mathrm{Mi} \\
+\mathrm{Ma}\end{array}$ & 3 & $\begin{array}{c}\text { F } \\
(\mathrm{Mi})\end{array}$ & $\begin{array}{c}\mathrm{I} \\
\text { (M) }\end{array}$ & $\begin{array}{c}\mathrm{I} \\
\mathrm{Ma}\end{array}$ & & & & & \\
\hline
\end{tabular}

5) Pola relasi antar unsur fungsi dalam konstruksi kalimat. Berbeda dengan bahasa Indonesia, dalam bahasa Arab relasi antar unsur ini sangat penting bahkan saling mempengaruhi terutama terkait jumlah (persona $\mathrm{M}$ atau $\mathrm{Mi}$ ) yang berjumlah 14 sebagai dalam morfologi (tashrif lugawi) dan jenis baik bentuk laki-laki (muzhakkar) atau perempuan (muannats). Untuk pola $\mathrm{M}+\mathrm{Mi}$ yang perlu diperhatikan adalah jumlah dan jenis. Sedangkan pola Mi + Ma yang perlu diperhatikan adalah jenisnya saja.

6) Cara membaca i'rab atau huruf terahir dari suatu kata dalam kalimat berdasarkan pola relasi antar unsur. Untuk membaca (memberi harakah atau vocal) secara utuh suatu kata atau bentuk dari kata dapat dibantu ilmu morfologi (sharf).
Sementara dalam kasus nahw pedagogis hanya membahas cara membaca huruf terahir kata dalam kalimat. Caranya adalah identifikasi kata berdasarkan fungsi dan kategori yang masuk ke dalam fungsi tersebut. Kata yang masuk dalam fungsi $\mathrm{M}$ dan MI jika dalam bentuk tunggal (mufrad) akan dibaca dummah, jika bentuk dua (mushanna) ditambah alif dan nun, jika plural laki-laiki (jamak muzhakar Salim) ditambah waw dan nun, jika plural perempuan (jamak muannash salim) ditambah alif dan ta' didummah, dan jika plural tak beraturan (jamak takshir) ditambah dummah.

Sementara jika frasa yang masuk ke M dan Mi terdiri dari ism dan ism maka ism pertama membacanya sama dengan jika ism sebelumnya. Sedangkan jika yang masuk ke M dan Mi adalah frasa maka harus diidentifikasi bentuk frasa itu terlebih dahulu. Jika frasanya terdiri dari harf dan ism, maka yang perlu diperhatikan adalah ism nya, karena harf bentuk dan cara membacanya tetap. Ism ini ada dua kemungkinan. Kemungkinan pertama adalah jika dalam bentuk tunggal (mufrad) bentuk akan akan dibaca dummah atau kasrah, jika bentuk dua (mushanna) ditambah ya' dan nun yang huruf sebelumnya dibaca fathah, jika plural laki-laiki (jamak muzhakar Salim) ditambah $y a^{\prime}$ dan nun, jika plural perempuan (jamak muannash salim) ditambah alif dan ta' dikasrah, dan jika plural tak beraturan (jamak takshir) ditambah fathah / dikasrah. Dibaca kasrah atau dummah ini diperlukan identifikasi jenis huruf yang masuk. Maka dalam hal ini identifikasi huruf itu penting.

Adapun Mi yang dimasuki kata kerja semua dibaca tetap. Khusus Mi yang dimasuki frasa yang terdiri huruf fi'il dan kata kerja maka yang perlu diperhatikan adalah fi'ilnya. dalam Kasus ini perlu melihat pola relasi dengan $\mathrm{M}$, jika $\mathrm{M}$ berpersona 1 laki-laki orang ketiga Mi akan dibaca fathah atau dummah dan jika 2 atau lebih laki-laki orang ketiga, 2 perempuan orang ketiga, 2 atau lebih laki-laki orang kedua dan 2 perempuan orang kedua cara membacanya adalah dengan membuang nun.

Sementara Ma yang dimasuki kata benda tunggal cara membacanya adalah jika dalam bentuk tunggal ( $m$ ufrad) dan plural tak beraturan (jamak tkasir) akan dibaca fahah, jika bentuk dua (mushanna) ditambah ya' dan nun yang huruf sebelumnya dibaca fathah, jika plural laki-laiki (jamak muzhakar Salim) ditambah ya' dan nun dan jika plural perempuan (jamak muannash salim) ditambah alif dan $t a^{\prime}$ dikasrah. Hal ini juga berlaku jika 
Ma berkategori frasa yang terdiri dari ism dan ism. Kecuali frasa ini berupa idafi, maka untuk mushanna dan jama' nun dibuang. Hal ini juga berlaku pada fungsi Fu. Fungsi ini cara membacanya adalah sama dengan Ma, kecuali pada frasa zharaf zaman atau makan.

\section{SIMPULAN}

Berdasarkan analisis di atas dapat disimpulkan bahwa Konsep ushul an-nahw dalam menyusun nahw bahasa Arab menggunakan tujuah metode, yaitu sama (naql atau riwayah), qiyas, ijma', ta'lil, ta'wil, 'amil dan istishhab dan Penerapan ushul annahw sebagai dasar penyusunan materi pembelajaran nahw pedagogis bisa dilakukan dengan lima tahapan, yaitu analisis terhadap metode-metode ushul an-nahw dalam menghasilkan teori nahw, penyisihan kaidah nahw, klasifikasi unsur-unsur deskriptifgeneral nahw, membandingkan unsur nahw dengan gramatika bahasa Indonesia sehingga ditemukan pola konstruksi nahw antar keduanya dan menyusun bahan ajar.

\section{DAFTAR PUSTAKA}

'Id, Muhammad. (2006). Ushul an-nahw al-'Arabi. Kairo: 'Alam al-Kutub.

A.M.W Pranarka. (1987). Epistemologi Dasar; Suatu Pengantar. Jakarta: Center For Strategic And International Studies Jakarta.

Afandi, Zamzam. (2008). "Bias Teologis dalam Linguistik Arab (?).” Jurnal Adabiyyat Bahasa dan Sastra Arab, vol. 7, no. 1 Januari-Juni, 133-152.

Afgani, Sa'id al-. (1987). Min Ushul an-Nahw. Bairut: Maktab al-Islam.

Ali, Atabiq dan Ahmad Zuhdi Muhdhor. 2004. Kamus Kontemporer Arab-Indonesia. Yogyakarta: Lembaga Ali Maksum Pesantren Krapyak.

Allah, Tamim. (2004). al-Batsit fi Ushul an-Nahw wa Madarihi. Malang: Litera Geraha al-Farabiy.

Anis, Ibrahim. (1975). Min Asrar al-Lugah. Mesir: Maktabah al-Anjlu al-Mishriyyah.

Badri, K.I.. (1986). Bunyah al-Kalimah wa Nuzhau al-Jumlah. Jakarta: Diktat Perkuliahan DIPLOM AM.

Chaer, Abdul. (2009). Sintaksis Bahasa Indonesia: Pendekatan Proses. Jakarta: PT Rineka Cipta.

Chomsky, Noam. (1957). Review of B. F. Skinner's Verbal Behavior Language. Cambrig: MIT Press.

Daif, Syauq. (1976). Al-Madaris an-Nahwiyyah. Mesir: Dar al-Ma'arif.

Goetz, Judith Preissle dan Lecompte Margaret. (1984). Ethnography and Qualitative Design and Education Research. Orlando: Academic Press Inc.

Hassan, Tammam. (1998). al-Ushul Dirasah Ibistimulujiyyah li al-Fikr al-Lugawi 'ind al-'Arab; anNahw. Fiqh al-Lugah wa al-Balagah. ii. Kairo: 'Alam al-Kutub.

Hassan, Tammam. (2000). Maqalat fi al-Lugah wa al-Adab. Kairo: 'Alam al-Kutub.

Hijazi, Mahmud Fahmi. (1973). 'Ilm al-Lugah al-'Arabiyyah: Madkhal Tarikhih Muqaran fi Dau' atTurats al-Samiyyah. Kuwait: Wakalah al-Mathbu'at.

Hughes, Jhon P. (1968). Linguistic and Language Teaching. New York: Random, House. 
Kridalaksana, Harimurti. (1984). Kamus Linguistik. Jakarta: Gramedia.

Ma'luf, Luwis. (2010). Al-Munjid fi al-Lugah wa al-A'lam. Beirut: Dar al-Masyriq.

Mada', Ibn. (1974). Al-Radd 'Ala an-Nuhat. editor. Syauqi Daif. Kairo: Dar al-Fikr al-'Arabi.

Malawi, Al-Amin. (2012). "Taisir an-Nahw al-'Arabi bain Tanzir wa at-Ta'lim.” Majalah al-'Ulum alInsaniyah, edisi 25 Mei, 211-225.

Mathlabi, Malik Yusuf Al-. (1986). Az-Zaman wa al-Lugah. Mesir: Al-Hai'ah al-Mishriyyah al'Ammah li al-Kitab.

McDermott, Martin J.. (1993). A Dictionary of Arabic Grammar Nomenlanture. Librairie du Liban Publisher.

Musa, 'Ata' Muhammad Mahmud. (1992). Manahij ad-Dars an-Nahw fi al-'Alam al-'Arabi fi al-Qarn al-'Isyrin. Disertasi. 'Amman: Takhassus al-Lugah al-'Arabiyyah wa Adabiha Kulliyah adDirasat al-'Ulya al-Jami'ah al-Urduniyyah

Mushthafa, Ibrahim. (1972). Al-Mu'jam al-Wasith. Juz II. Istanbul: al-Maktabah al-Islamiyyah. cet. ii.

Parera, Jos Daniel. (1987). Linguistik Edukasional: Pendekatan. Konsep dan Teori Penagajaran Bahasa. Jakarta: Erlangga.

Pateda, Mansoer. (1991). Linguistik Terapan. Flores: Nusa Indah.

Putrayasa. Ida Bagus. (2014). Analisis Kalimat Fungsi. Kategori dan Peran. Bandung: Rafika Aditiya.

Ramlan, M.. (2005). Ilmu Bahasa Indonesia: Sintaksis. Yogyakarta: C.V. Karyono.

Setyawati, Nanik. (2010). Analisis Kesalahan Berbahasa Indonesia: Teori dan Praktik. Surakarta: Yuma Pustaka.

Stern, H. H.. (1983). Fundamental Concepts of Language Teaching. Oxford: Oxford University Press.

Suhardi. (2008). Sintaksis. Yogyakarta: UNY Press.

Tarigan, Henry Guntur. (1986). Teknik Pengajaran Keterampilan Berbahasa. Bandung: Angkasa.

Ushalli, 'Abd al-'Aziz ibn Ibrahim al-. (2009). An-Nazhariyyat al-Lugawiyyah wa Ta'lim al-Lugah al'Arabiyyah. terj. Jailani Musni. Psikolinguistik Pembelajaran Bahasa Arab. i. Bandung: Humaniora.

Wahab, Muhbib Abdul. (2009). Pemikiran Linguistik Tammam Hassan dalam Pembelajaran Bahasa Arab. Jakarta: UIN Jakarta Press.

Yaqut, Ahmad Sulaiman. (1992). Fi 'Ilm al-Lugah al-Taqabuli. Iskandaria: Dar al-Ma'arifah. 